\title{
Development of Music Education Specialties in Conservatories of Music in China
}

\section{Chen Li}

\author{
College of Music , Jiangxi University of Technology
}

\begin{abstract}
Keywords: Music education; Music education specialties in Conservatories of Music; Training objects; The curriculum; The teaching staff
\end{abstract}

\begin{abstract}
In this paper, the author takes music education specialties in nine Chinese Conservatories of Music as direct study objects, and conducts horizontal comparison and analysis from the aspects of training objectives, the curriculum and teaching staff, so as to state the history, the current situation and the responsibility borne by the music education specialties in Conservatories of Music in China. Then, the author puts forward that all Conservatories of Music should reflect their own characteristics in the development of music education specialties, the advantages and the disadvantages all Conservatories of Music have, and a number of possible reform plans. On this basis, the author further discusses the strengths, the weaknesses and the foothold of the music education specialties in the Conservatory of Music to explore the future trends and potential possibilities of the music education specialties in the Conservatory of Music in China.
\end{abstract}

\section{Introduction}

In the researching field of music education theory, the mono-graphic study on music teaching programs in the Conservatories of Music is basically empty. The central topic of this paper is to conducts horizontal comparison and analysis from the aspects of training objectives, the curriculum and teaching staff, so as to state the history, the current situation and the responsibility borne by the music education specialties in Conservatories of Music in China. Then, the author puts forward that all Conservatories of Music should reflect their own characteristics in the development of music education specialties, the advantages and the disadvantages all Conservatories of Music have, and a number of possible reform plans. On this basis, the author further discusses the strengths, the weaknesses and the foothold of the music education specialties in the Conservatory of Music to explore the future trends and potential possibilities of the music education specialties in the Conservatory of Music in China.

The study objects of this paper are the Departments of Music Education (Education) in nine domestic senior conservatories of music, which are the Shanghai Conservatory of Music, the Central Conservatory of Music, the China Conservatory of Music, the Shenyang Conservatory of Music, the Sichuan Conservatory of Music, the Wuhan Conservatory of Music, the Xi'an Conservatory of Music, the Xinghai Conservatory of Music and the Tianjin Conservatory of Music. The paper consists of three parts, each part centering on one particular issue in discipline construction of professional music majors and conducts comparison and analysis with each school. The first part of this paper discusses subject orientation, training objects and training standard (requirements) of the music education specialties in the nine Conservatory of Music, and the author in this part conducts 
comparison them with the relevant requirements specifies in the Education files issued by the National Education Department. Then, the author centers on the curriculum in the Departments of Music Education in each conservatory of music and discusses their similarities and differences, as well as map out the teaching principle. In the second part, the author analyzes the current teaching staff in nine conservatories of music, the resource and the faulty appointment system.

After analysis and comparison of the current situation of music education specialties in nine Conservatories of Music, the author compares the advantages and the disadvantages of "each music education specialty under the background of the Conservatories of Music" and then starts discussions on the issues of "how to gain their own unique position in this era and the background", and the "subject task" in the epilogue. Finally, the author discusses the common problems of the Departments of Music Education in all Conservatories of Music are facing: the student source, the overall quality required to the students, the conflicts in the actual training mode, and the flexibility and diversification in course selection, etc.

In fact, many Conservatories of Music in their early establishment set up normal specialties. Due to the main training subjects of many Conservatories of Music back then were to raise professional music performers and theoretical researchers, thus the music education specialties have been neglected or even been ceased in a very long period. After the founding of New China, the demand for music teachers in the primary schools and the secondary schools soars. Only relying on the teachers trained by the Departments of Music Education from the Senior Normal Colleges can not meet this demand, either in quality or in quantity. After the entrance into the 1970s, to meet the needs of the rapid development of music education, the Ministry of Education brought forward that "The Conservatories of Music should bear the responsibility of training teachers for the primary schools and the secondary schools." Under such historical background, many Conservatories of Music re-opened or newly set up the music education specialties. As the new force of Advanced Normal Music Education, the music education specialties re-opened or newly set up not only breaks the original situation that all professional music performers and theoretical researchers brought up by the Senior Normal schools, bringing the fresh blood to China's music education. As the music education specialties are specialties combining music with education, if cultivated them in Conservatories of Music, their development will have a unique condition: support teaching and professional research strength of its Higher School of Music is obvious. This "proximity" of the teaching environment is very contribute to music education professional development. However, a considerable period of time, the Ministry of Education on the policies and regulations, it seems that the music Conservatory of Higher Education set the development of attitude. Thus Conservatory of nine one can be described as a music education prevails, there is no uniform model, presented flowers and put the situation in this context to China nine Conservatory of Music Department of Education building concept and operation of the status quo as a comb and a comparative analysis is very necessary and practical significance.

\section{Development of music education specialties}

The beginning of the new century, our country entered a new stage of accelerating socialist modernization. The world economic globalization and the rapid development of science and technology make countries competition in overall national strength is becoming increasingly fierce. The new situation of education in training and bring up a new generation of high quality in the 21st century in our country and proposed the new requirements of more pressing. Music is born of 
knowledge structure in addition to the regular discipline knowledge, art's unique role in the formation of personality character more and more attention. Gardner, an American psychologist, put forward the concept of "multiple intelligence" is typical of the interpretation of such concepts. Thus, but only strengthen the school art education in China, is the current boost all-round quality education and promote the healthy growth of students all-round development and an urgent task. School art education is the main way to implement aesthetic education school and content. The $13^{\text {th }}$ Document issued by the Ministry of Education of the People's Republic of China. "School art education operating rules", "national school art education development plan (2001-2010) and the ministry of education of the art course standard" (ministry of education) promulgated on art education teachers put forward higher request.

To fully implement the education policy, we will conscientiously implement the school art education operation procedures, further deepening the comprehensive study, normal schools, art schools (including) musicology (teacher education) reform of undergraduate majors, improve the teaching quality of education and training to adapt to the school music education needs high quality talents, the ministry of education to entrust the national education science "fifteen" plan key subject "primary and secondary school music education development and the higher normal music education professional education teaching reform" group to develop the national musicology (teacher education) of common colleges and universities undergraduate course guidelines "hereinafter referred to as" the program). Research at home and abroad in musicology (teacher education), undergraduate education in common colleges and universities teaching situation on the basis of extensive investigation and in-depth analysis, according to the musicology (teacher education) the needs of the development of reform of undergraduate majors, drafted the course plan draft.

The course plan contains the content of the music education professional training objectives, training specifications, curriculum structure, class hours credit allocation and practice etc. In fact, nine music college music education specialty are according to their respective actual situation to carry on the discipline orientation, formulate objectives such as discipline construction. In the process of discipline construction, determine the training objectives is crucial to the development of discipline. The establishment of training objectives directly set we investigate what race to cultivate talents, directly affect the positioning of the discipline. The training goal, the resulting is curriculum support. Cultivate different talented person need to completely different course system to support, if there is a deviation training goal, the whole subject curriculum will present different structure, a completely different direction. So-called a miss great difference, eventually lead to the curriculum does not conform to the subject characteristics.

In the nine Conservatories of Music, the foothold and the training objectives of the Central Conservatory of Music are very special.

\section{The training direction and the main principle of the Central Conservatory of Music is}

The curriculum "set in the people heart and soul music education professional ideas, to the education reform in the field of the unremitting and hard exploration and practice, not only to master the basic music knowledge and basic skills of music, the artistic nature of music and aesthetic manifestations, has led the educatees to participate in the activities of music and the ability to appreciate music, more must be done through their singing, music, and dance music practice, laying a solid foundation of music and a certain artistic accomplishment, in music and music quality meet the requirements of teachers qualities, and must be familiar with and master the national folk music 
language, style and documents, and put them as the basic material of music practice and teaching; should not only through the theory study, need more through their own practice, sing, play, do) as well as the specific teaching practice to master the basic principles of education and the basic technology, make its have classroom music teaching and the ability of school music activities; familiar with contemporary advanced international music teaching method and its basic teaching materials, filtered according to different objects and adaptation ability." From the perspective of the principles of in, the training objectives of the Central Conservatory of Music are different from that of other eight Conservatories of Music, it requires the cultivation of talents in the premise of qualified school music teacher, to be able to "education reform in this field to carry on the unremitting, arduous exploration and practice", can through continuous in-depth research for music education reform of benign. Department, on the other hand, the introduction of the teaching system into a giant, especially kodak, orff teaching system and teaching system, its rise as the core of undergraduate professional courses, teaching should be used in the original teaching material, beginning from the build system by continuously, short or long period to the qing, Mr, Hungary, than, countries such as specialized teachers, taught systematically and deeply. Hungary to the kodak in accordance with the research center and international orff foundation to establish a long-term relations of cooperation. In April 2002, the school of music "orff music education research center", "big foundation with Germany and Austria orff institute jointly established the national orff music education of teachers training, all kinds of music to students of music education and in-service teacher training system. Held at the end of September 2002, titled "listening to the sound of the world" international conference, meeting with orff music works and music teaching materials play a concert, show orff music education system in essence. In short, the training objectives of the Central Conservatory of Musicfocuses more on the professional music teachers and professional theory research, many of the new curriculum and experimental teaching practice with strong. Discipline builders hope it into music education theory and the research experiment teaching system of the base, well through continuous research and experimental teaching practice, based on a set of their own music teaching system.

To sum up, in addition to the the Central Conservatory of Music, other music college music education on cultivation objectives and specifications, basically in conformity with the ministry of education put forward guidance. And, of course, some of the college to "personality" adjustment.

It is noteworthy that "course program" specific training specifications mentioned a little too idealistic, some specific requirements are now being discussed in academic circles repeatedly and vehemently, some institutions tend to neglect some of the practical significance and value of the claim. Such as "course program" in the "harvest can use a computer, analyzing and processing information;. Has an operating capacity of modern teaching methods that emphasize training specifications ability to use a computer, can not only skillfully operate, but also with the information through a computer collection, classification, the ability to compare in addition, it requires the use of computer-assisted instruction: courseware and audio, basic editing of video data processing.

With the rapid development of computers, more and more teachers will be cloud computing into practice teaching, teaching practice has proved that it can help teachers to basic knowledge in real-time point of illustration and description, so that students are more intuitively what they learn something awareness, improve students' enthusiasm, active classroom atmosphere. So, how to properly use this tool became assistant teaching music education major new topics. However, the majority of Conservatory Music Education in culture does not have a clear specification of 
requirements, only "able to use modern equipment for teaching, " "computer operating levels meet the state standards and the school" provides a kind of vague requirements. These can not meet demand. Indeed, the Ministry of Education is developing the "policy guidelines" really for the music, "teacher education" put forward concrete implementation of views, but in fact the original intention of the program developed by the Ministry of Education or the Department of Music for Higher Teachers College, but in the description incidentally referred to art school. The music education nine tertiary institutions in the vast majority of music is just only for reference, the independent development of training objectives and specific requirements. Depending on the final focus and direction of the training objectives established, we can nine Chinese Conservatory of Music Education Program targets grouped into the following categories:

\section{First Type: Experimental Type}

The music education major in the Central Conservatory of Music is a typical representative. Talent training is focused on training theory, research talents, build all kinds of courses experimental model, in the form of teaching practice for the inspection and testing die punishment.

\section{Second Type: the Target-driven Type}

The biggest characteristic of the Target-driven Type of the music education specialties in Conservatory of Music is: to cultivate music teachers as the main task, consideration with other types of music related to train talents, such as literature and art groups in society, art research unit, and the education authorities published transmission unit specialized personnel engaged in the work of education and research. the music education specialties in the Wuhan Conservatory of Music, the China Conservatory of Music, the Tianjin Conservatory of Music, the Shenyang Conservatory of Music and the Sichuan Conservatory of Music belong to this type.

the Shanghai Conservatory of Music, the Central Conservatory of Music, the China Conservatory of Music, the Shenyang Conservatory of Music, the Sichuan Conservatory of Music, the Wuhan Conservatory of Music, the Xi'an Conservatory of Music, the Xinghai Conservatory of Music and the Tianjin Conservatory of Music.

\section{Third, developmental steadily}

Most music education specialties in colleges belong to this type. They are loyal to their "original aimes", namely, training teachers in the process of constantly deepen education reform, make tend to be more into heat and perfect their own. Belonging to this kind of colleges and universities are the music education specialties in the Wuhan Conservatory of Music, the China Conservatory of Music, the Tianjin Conservatory of Music, he Shenyang Conservatory of Music and the Sichuan Conservatory of Music

\section{Conclusions}

in nowadays China's higher education, music teacher education generally focus on one or two categories of colleges and universities, one is the music specialty in higher normal colleges and universities, the second is music in the music colleges education professional. Higher normal colleges and universities of professional music after the founding of the decades of trial and error, 
compiled a set of teaching system, and basically adapt to the present situation of our country. In the past quite a long period of time for our country's music education career made great contribution. Teaching system, however, is only at a certain time to adapt to the specific political, economic and cultural development. From a more macro perspective, this still needs to be in the development of the teaching system. With the deepening of national reform and opening up and the ongoing curriculum reform, the teaching system already can not adapt to the needs of China's political, economic and cultural development.

\section{Acknowledgements}

Jiangxi Senior Education Innovation Research Topic: "Chinese folk dance curriculum reform and innovation of research", project number: JXJG-14-24-14

\section{References}

[1] "music teaching doctrine and practice, " the authors Ou Kang, Datong Press (Taiwan)

[2] "music pedagogy" by Zhang Fangrui, Hunan People's Publishing House, 1981 edition

[3] "Music teaching and research, " the authors Zhang Tong Xing, the whole musical spectrum Press (Taiwan) 1982

[4] "primary and secondary school music teaching manual, " by He Daming, Jiangxi People's Publishing House in 1982 edition

[5] "Dalcroze Eurhythmics school entry, " the authors Delaiweier, Goh Jin translation, Anhui Literature Publishing House, 1986 edition

[6] "Music education enlightenment" by Deng Guanghua, Liu Xinglun, Guizhou People's Publishing House, 1987

[7] "Music Education" by Cao Li, Guangming Daily Press, 1987

[8] "Orff children's music pedagogy preliminary" by one account Nier Te · Kaite Man, Liaonai Xiong Ze, Anhui Literature and Art Publishing House 1987

\section{Edition}

[9] "Music Education" by Cao Li, Lee Park Min light's Daily Press, 1987

[10]"Principles and methods of teaching music, " by Lee obliterate, Quang Trung, Hunan Education Press, 1988 edition 